\title{
INTERNATIONAL TRADE ADMINISTRATION COMMISSION TARIFF INVESTIGATIONS: AN ANALYSIS OF THE POULTRY AND PAPER CASES
}

\author{
Marko Kwaramba* \\ University of Johannesburg \\ Kwarambamarko@gmail.com
}

Received: June 2014

\author{
Fiona Tregenna" \\ University of Johannesburg \\ ftregenna@uj.ac.za
}

Accepted: September 2014

\begin{abstract}
This paper critically evaluates the role and performance of the International Trade Administration Commission of South Africa (ITAC) with a focus on tariff investigations. The paper analyses ITAC's poultry and paper tariff investigations. For both of these cases, we analyse the economic context, assess parties' submissions and perceptions of the tariff investigation processes and outcomes, evaluate the duration of the investigation, consider the balancing of the various interests involved, and analyse ITAC's recommendations. From these two important cases it appears that ITAC has changed its approach to tariffs in line with developments in South Africa's trade policy. The findings also indicate that ITAC is not yet consistently meeting the stipulated tariff investigation timeframes. Possible policy implications arising from the analysis are discussed.
\end{abstract}

Keywords:

Trade policy, tariffs, imports, institutional performance, poultry, paper

*Mr M Kwaramba is an affiliated lecturer in the Department of $\varepsilon$ conomics and Econometrics, University of Johannesburg, South Africa.

\#Prof F Tregenna is a professor in Department of Economics and Econometrics, University of Johannesburg, South Africa. 


\section{INTRODUCTION}

In 2009 there was a significant shift in South Africa's trade policy, away from the liberalisation of the earlier post-democracy period to selective and strategic trade policy. The recently released 20-year Review aptly captures this shift in policy: 'From the late 2000s, trade reforms shifted to more targeted efforts, with considered use of safeguard measures, local procurement and other interventions geared to fostering industrialisation and job creation' (Presidency of the Republic of South Africa, 2014:96). In the post-2009 tariff-setting regime, tariffs would be either increased or decreased depending on particular industries' circumstances and other considerations.

What is not clear from the existing literature is the extent to which the International Trade Administration Commission of South Africa (ITAC), as the institution mandated to implement trade policy in South Africa, has managed to implement these trade policy changes in its work. The objectives of this study are therefore to review and evaluate the tariff-setting role of ITAC, with reference to the poultry and paper cases. It investigates the robustness of ITAC tariff decisions given the changes in trade policy. The first is the 2006 paper case which covers the tariff liberalisation phase. The second is the 2013 poultry sector, which is set in the period when tariff liberalisation was no longer the general policy framework. This study evaluates the decision reached by ITAC in these two cases from an economic standpoint, and considers the implications for the overall role and performance of ITAC. ITAC plays a crucial role in the implementation of South African trade policy, and this analysis has important policy implications.

ITAC was established on 1 June 2003 in terms of the International Trade Administration Act (Act 71 of 2002) (the ITA Act), which replaced the Board on Tariffs and Trade Act (Act 107 of 1986). The responsibilities of ITAC lie in three areas: tariff investigations, trade remedies and import and export control. The focus of this study is on the tariff investigation role.

ITAC is not responsible for setting trade policy but rather for implementing trade policy that is set by the Department of Trade and Industry (DTI). ITAC carries out its mandate within the broader economic policy framework of the South African government, in particular as articulated by the Economic Development Department (EDD) and DTI. The South African Trade Policy Review (TPR) draft document calls for a strategic review of tariffs to support industrial development (DTI, 2010). The TPR states that trade policy needs to be in compliance with the National Industrial Policy Framework (NIFP) for it to promote diversification, which helps sectoral tariff determination. South African trade policy is thus seen as an important instrument of industrial policy.

The primary contributions of this study are twofold. Firstly, a detailed micro-level analysis is undertaken of ITAC's role in undertaking investigations and making tariff recommendations for the poultry and paper sectors. Unlike existing studies that focus on the impact of tariff liberalisation on the economy as a whole or on individual sectors using econometric methods (see for instance Harding \& Ratts $\varnothing$, 2010, Fiandeiro \& Rankin, 2008, Thurlow, 2006), the focus here is primarily at the micro-level as to how tariff decisions are actually undertaken and give possible evaluations taking into account the evolution of South Africa's trade policy and institutions capabilities. This study tracks specific products at Harmonised System (HS) 6 digit tariff lines, shedding light on microeconomic issues that might be not revealed by macro or broader sectoral studies. Secondly this study is unique in combining institutional analysis with empirical analysis of specific sectors and cases. While there are a number of existing empirical 
analysis related to trade in South Africa, and there are various existing institutional analysis (although not necessarily of ITAC), this article contributes to the literature by bringing together these two angles. Linked to this, the study examines the recent evolution of South Africa's trade policy and the implementation thereof, through the lens of the specific cases of the poultry and paper tariff investigations.

This article is structured as follows. The next section sets out the methodology. Section 3 provides relevant background on ITAC's tariff investigations process and the relationship with South African trade policy. Sections 4 and 5 analyse the paper and poultry industry cases respectively. These case studies examine the economic context of the investigations, the submissions made by stakeholders, how ITAC took various considerations into account in arriving at their recommendations and a critical analysis of the ITAC decisions. Review and discussion of the relevant literature is integrated throughout the document where appropriate rather than being in a separate section. Section 6 concludes and offers some recommendations, drawing from the analysis in sections 4 and 5 .

\section{METHODOLOGY}

Both qualitative and quantitative methodologies are used in this research. Relevant documents were sourced and analysed, including documents in the public domain as well as those made available to the authors for the specific purposes of this research.

A number of interviews were conducted, including with ITAC staff, government departments, experts, and stakeholders involved in the two cases analysed. The appendix lists the interviewees. The study employs the purposive sampling procedure, since it focuses only on those who are knowledgeable and directly linked to the decision-making of ITAC. The study thus utilises key informant interviews. None of the interviewees requested anonymity. The interviews were conducted in a semi-structured manner, based on a guiding set of questions but allowing for free discussion and the sharing of additional information.

This qualitative data obtained through interviews is complemented with the analysis of secondary data obtained from the poultry and paper industry associations, ITAC, Quantec and the South African Revenue Services (SARS).

\section{BACKGROUND}

\subsection{The process of tariff investigations at ITAC}

ITAC receives and evaluates cases from local industry applications for tariff reductions or increases. ITAC obtains information by sending templates which companies are required to complete, indicating financial information, costs, inputs and any other information that support the application. ITAC also visits companies in order to verify the information submitted. Local industry submits cases for duty increases, in order to seek relief from external competition, or tariff-reduction cases to lower duties on goods such as raw materials and intermediate inputs that are not manufactured locally (this is to allow domestic companies to become more competitive). ITAC investigates these cases, analysing the impact on the economy and effects on employment, growth and investment in particular. ITAC forwards its recommendations to the Minister of Trade and Industry for a final decision, which is then forwarded to the Deputy 
Minister of Finance and once approved the tariff changes are submitted to SARS for implementation. The tariff investigation timeframe was revised from the previous twelve months to four months for sectors in distress and six months for normal investigations (ITAC, 2013a). The tariff investigation process is illustrated in FIGURE 1.

\begin{tabular}{|c|c|c|c|c|c|c|}
\hline $\begin{array}{l}\text { Receipt of } \\
\text { Application } \\
\text { documented in } \\
\text { form of } \\
\text { standard } \\
\text { questionnaires }\end{array}$ & \begin{tabular}{|l|} 
Preliminary \\
investigation \\
on prima facie \\
evidence. \\
Interested \\
parties \\
invited to \\
comment
\end{tabular} & $\begin{array}{l}\text { Initiation of } \\
\text { Investigation } \\
\text { through } \\
\text { publication } \\
\text { in the } \\
\text { Government } \\
\text { Gazette }\end{array}$ & $\begin{array}{l}\text { Final } \\
\text { determination } \\
\text { by the } \\
\text { Commission and } \\
\text { recommendation } \\
\text { to the Minister }\end{array}$ & $\begin{array}{l}\text { Minister } \\
\text { considers } \\
\text { Commission's } \\
\text { recommendation }\end{array}$ & $\begin{array}{l}\text { Minister of } \\
\text { Trade } \\
\text { request } \\
\text { Minister of } \\
\text { Finance to } \\
\text { implement }\end{array}$ & $\begin{array}{l}\text { SARS } \\
\text { implements } \\
\text { the final } \\
\text { decision }\end{array}$ \\
\hline
\end{tabular}

\section{FIGURE 1 ITAC investigation process}

Source: ITAC, $2013 a$

The International Trade Administration Act provides the legal basis for undertaking investigations and making recommendations regarding customs duty amendments. The ITA Act (sections 38-45) provides the legal basis for ITAC's powers of investigative search and inspection. The High Court or regional magistrate or a magistrate may issue a warrant to enter and search any premise (ITA Act, section 43). ITAC has powers to enter and search without a warrant (ITA Act, section 44). ITAC also operates under the Tariff Investigation Regulations, which provide clarity and assist parties that wish to bring a customs duty amendment application.

Section 60 of the ITA Act accords ITAC the power to put out Tariff Investigation Guidelines, which provide guidelines on the procedures that parties need to follow when applying for tariff changes. The purpose of the guidelines is to operationalise the regulations. The Tariff Investigations Guidelines are revised in the context of changing policy as well as changing domestic and global conditions. The focus of the revised guidelines is on thoroughness and strengthening analysis in support of the rationale behind any recommendations. They set out a systematic and coherent approach to analysing tariff applications, facilitating more effective comparison and focused assessment of applications (Interview with Chief Economist).

\subsection{Tariff investigations in the context of changing South African trade policy}

ITAC reviews its tariff investigation guidelines to align these to government policy. Currently, ITAC is following a 'developmental or strategic approach to tariff setting with the objective of promoting domestic manufacturing activity, employment retention and creation, and international competitiveness' (ITAC, 2013:11).

According to the ITAC Chief Economist, ITAC has increasingly adopted a hands-on approach in investigating tariffs changes demands by the local industries. The tariff application assessment and adjudication is not based only on information provided by an applicant (a companyspecific approach). Investigations now entail an industry-wide approach, analysing relevant industry information. ITAC's tariff investigations are evidence-based, and are carried out on a case-by-case basis, employing simple trend and comparative methodology in assessing applications. 
ITAC now makes tariff support conditional on reciprocal commitments by applicants. These are intended to ensure that beneficiaries of tariff decisions contribute to advancing the policy objectives of increased domestic manufacturing, investment, value addition and competitiveness. The reciprocity assessment approach entails that if the government changes tariffs it expects a reciprocal positive contribution to the economy, such as increasing employment, investment and domestic manufacturing activities.

ITAC has changed its outlook and decision-making in response to the changes in trade policies. The Chief Commissioner of ITAC has noted that, whereas previously the push was towards tariff liberalisation, the approach now is evidence-based on a case-by-case basis, with no priors about whether tariffs should be increased or decreased. Instead, recommendations as to whether to increase or decrease tariffs are informed by a weighing up of strategic objectives and considerations on particular products.

The interviewee from EDD notes that changes in trade policy over the past five years and the resultant changes in ITAC's mandate have the effect of requiring ITAC to be significantly more active and activist in its work, in particular more active in using import duties as a tool and much more strategically than previously. In his assessment, ITAC is sufficiently aware of the changes in mandate; they are indeed doing things differently from previously and are essentially managing to achieve the current mandate.

\section{PAPER CASE STUDY}

\subsection{Background}

The Printing Industries Federation of South Africa (PIFSA) made a request to ITAC for a reduction in the rates of duty on paper and paperboard covering 81 tariff subheadings. The printing, publishing and packaging companies are involved in value addition of paper by converting it into a variety of products such as books, magazines and packaging material. The industry is composed of 844 members, which are small to medium-sized companies. This is the opposite of the paper industry, which is dominated by Sappi and Mondi.

The paper industry contributes about $0.6 \%, 3.9 \%$ and $27.5 \%$ to gross domestic product (GDP), manufacturing GDP and agricultural GDP respectively in 2011 (Paper Manufacturers Association of South Africa (PAMSA), 2013). FIGURE 2 shows the production and import of total paper from 2001. Production has been fluctuating, apart from for 2008 that shows a marked decline possibly due to the global crisis. It shows that imports were not very high pre-2006. This might be a reason why PIFSA requested a tariff reduction. 


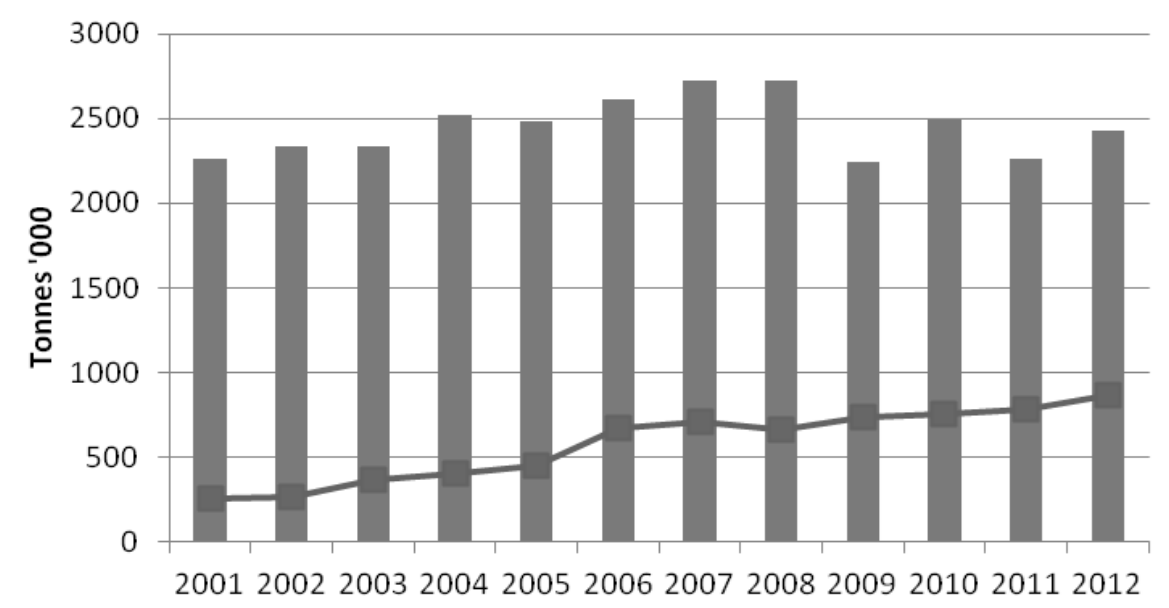

Total Paper Production (tonnes ('000) $\rightarrow$ - Paper imports (tonnes ('000)

\section{FIGURE 2: Trends of total paper production and imports}

\section{Source: Derived from PAMSA, 2013}

\subsection{PIFSA application and stakeholder concerns}

The PIFSA application was published in Government Gazette No. 27579 (20 May 2005), and interested parties were invited to make submissions. Four companies in the industry and PIFSA supported the application, while one company and PAMSA objected to the application.

PIFSA and other companies gave various reasons for the need for tariff reductions on paper and paperboard. They argued that the domestic paper manufacturing industry was highly concentrated, hence the need for imports to provide an alternative form of competition. The five largest manufacturers are Sappi, Mondi, Nampak, Gayatri and Kimberly-Clark. The combined output of these five manufacturers was about $96 \%$ of pulp, paper and paperboard production in South Africa. The largest among these five is Sappi, which is ranked $20^{\text {th }}$ by turnover, and Mondi, ranked $15^{\text {th }}$ on the list of the largest pulp and paper companies in the world.

The grouping in favour of the reduction of duties provided evidence in relation to the projected impact of a tariff reduction on employment, growth and sustainability of the industry across the value chain industry. It was argued that those who were against the duty reduction were interested only in protecting their uncompetitiveness, since the industry was highly concentrated with high barriers to entry. They believed that a reduction in tariffs would have a cost-cutting effect on the downstream industry, which is a major exporter. PIFSA provided an argument around a growth strategy for the industry in the form of employment, investment and sustainability of the agricultural sector. They also argued that either some products were not manufactured in SACU, or that sufficient time had passed for those large international corporations to become competitive in these markets. Another reason advanced by PIFSA was the long-term contracts that paper manufacturers enter into with local printing, packaging and publishing companies, which creates inflexibility in the face of increased demand. 
Those who were against the duty reduction cited the evolution of custom duty dispensation in the industry since 1992, non-tariff barriers in some overseas countries and the price trends and the effects of import tariffs on the prices.

ITAC's analysis was largely based on developments in the duty structure of the SA-EU tariff phase-down. The import analysis showed that the $\varepsilon U$ and SADC accounted for $76 \%$ of imports for tariff headings $48.01,48.02,48.05,48.07,48.08,48.10$ and 48.11 . These imports were either duty-free or their duties were in the process of being phased down to duty-free by 2012. ITAC therefore aligned its recommendations in tandem with the evolution in the duty structures of the EU. ITAC also took into account the competitive advantage of the domestic industry; cost raising effects on downstream industry; the investigation by the DTI on import parity pricing; and tariff policy in respect of input materials on raising prices.

The existing tariffs on some products in 2006 before the tariff reduction were $5 \%$ on newsprint products under tariff subheadings $4801.00 .10,4801.00 .20,4802.54 .20,4802.54 .20$ and uncoated kraft paper and paperboard under tariff subheading 4804.11, 4804.19, 4804.21, 4804.52 and $4804.59 ; 10 \%$ on carbon paper and self-copy under tariff subheadings 4816.10 and $4816.20 ; 15 \%$ on paper and paperboard and cellulose wadding under tariff subheadings 4811.10 .10 and 4811.90.10; and $20 \%$ on paper and paperboard, cellulose wadding under tariff subheading 48114190 (PAMSA, 2006).

\subsection{The outcome}

ITAC recommended a differential gradual reduction of duties on different paper products to a duty-free rate. For example, reduction of products at $5 \%$ ad valorem to duty-free immediately, those products at $10 \%$ and $15 \%$ to duty-free by 2012 , and finally those products charged duty of $20 \%$ (for HS4811.41.90) to duty-free by 2015. Following the SA-EU tariff phase-down the recommended different tariff categories are as shown in TABLE 1 .

TABLE 1: SA-EU tariff phase-down

\begin{tabular}{cccc}
\hline Year & Products at 20\% & Products at 15\% & Products at 10\% \\
\hline 2005 & $20 \%$ & $13.2 \%$ & $8.8 \%$ \\
2006 & $18 \%$ & $11.25 \%$ & $7.5 \%$ \\
2007 & $16 \%$ & $9.45 \%$ & $6.3 \%$ \\
2008 & $14 \%$ & $7.50 \%$ & $5.0 \%$ \\
2009 & $12 \%$ & $5.70 \%$ & $3.8 \%$ \\
2010 & $10 \%$ & $3.75 \%$ & $2.5 \%$ \\
2011 & $8 \%$ & $1.95 \%$ & $1.3 \%$ \\
2012 & $6 \%$ & Free & Free \\
\hline 2013 & $4 \%$ & & \\
\hline 2014 & $2 \%$ & & \\
\hline 2015 & Free & & \\
\hline
\end{tabular}

Source: PAMSA, 2006 
ITAC's recommendation led to tariff reductions on paper and paperboard products based on this tariff phase-down schedule, with backing from import data. For example under tariff heading 48.08 all duties were $5 \%$ with $94 \%$ of paper and paper board being imported from the $\varepsilon U$ and SADC. Because of the free trade area with the SADC and the $\varepsilon U$, they saw no justification for retaining the $5 \%$ duty, hence the duty was removed. A similar analysis was applied to all products.

\subsection{Analysis}

The evaluation of ITAC on the paper case is based on the following considerations: using imports analysis to decide on tariff reduction (considering the developments in the duty structure of $\varepsilon U)$; time taken by ITAC to make final decision on cases; bias in favour of small companies against big companies; and the need for deeper understanding of different tariff lines of paper.

Imports of paper products have been increasing at 3.5\% per annum since 2006 (PAMSA, 2013). PAMSA is therefore concerned about the effect of this on the paper sector, as this might continue leading to further company closures. The 2008 global crisis led to a temporary reduction of imports, but these however have grown to $30 \%$ since 2008 (PAMSA, 2012). In their view, these developments are exerting increasing pressure on local production. The negative balance of trade rand value of paper and board (excluding pulp) has more than doubled since 2008. FIGURE 3 shows that from 2006 imports of printing paper are greater than exports; this is similar to tissue paper and opposite from packaging papers. This shows that after the reduction of duty rates on different HS lines imports have been increasing for printing and writing paper.

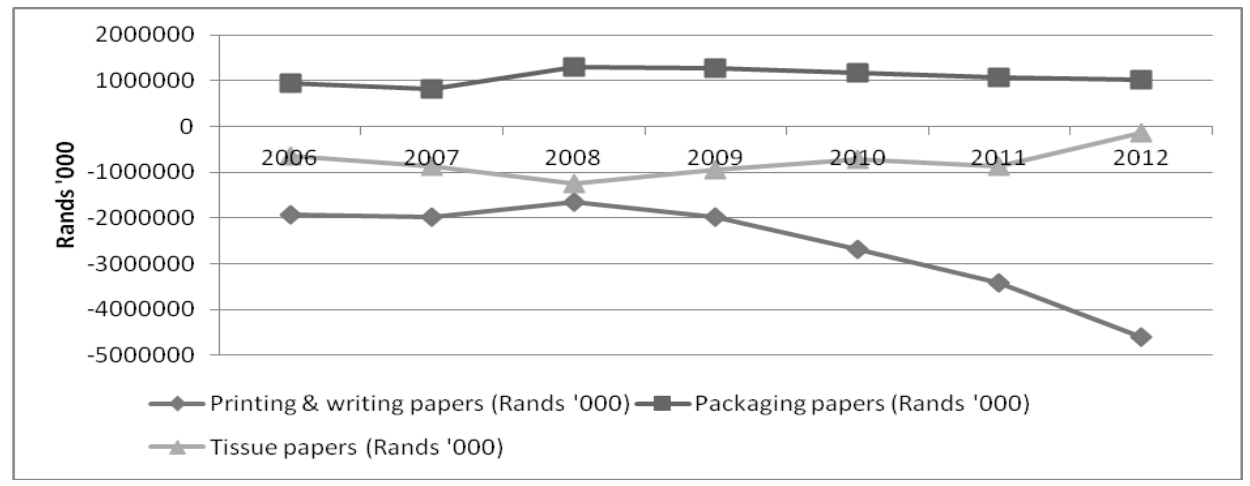

\section{FIGURE 3: Balance of Trade (exports-imports)}

Source: Derived from PAMSA, 2013.

A possible weakness of ITAC's technical analysis in this case lay in the strong basing of their decision on import analysis and trade agreements. The reduction of all tariffs over a number of years because of a trade agreement consideration may take insufficient account of other important economic considerations. Although ITAC also considered factors such as the DTI's investigation on import parity pricing, the competitive advantage of the domestic industry, cost raising effects on downstream industry, and tariff policy in respect of input materials on raising prices, these considerations appeared to be secondary to issues around trade agreements.

However, it needs to be borne in mind that this investigation was done nine years ago, at a time when the policy was still to reduce duties and only consider increases as an exception. ITAC was 
therefore following the direction of South Africa's trade policy at that time. The tariff reduction phase was the existing framework that gave context to this particular investigation and recommendation.

PAMSA takes the view that the decision to unilaterally decrease tariffs on paper and paperboard based on the SA-EU tariff phase-down was flawed. It argued out that this is one of the reasons why it applied for this tariff reduction reversal (Interview with PAMSA). In 2013 PAMSA applied to ITAC for tariff reversal on some of these products on which tariffs were reduced in 2006. For example, PAMSA submitted an application for the increase of tariffs on uncoated paper and paper classified under tariff subheadings HS4802.56.90 and HS4802.56.20 (Government Notice of 180 ctober 2013). The other application is on tariff line HS4810.19.90 (dated 90 ctober 2013). TABLE 2 shows applications by PAMSA on some products for tariff reversals. ITAC is still to make final decisions concerning these products.

\section{TABLE 2: Tariff lines for duty reversal}

\begin{tabular}{rll}
\hline HS line & 2006 action (from demands by PIFSA) & 2013/14 demands by PAMSA \\
\hline 48025620 & Reduction of duty from 5\% to duty-free rate & $\begin{array}{l}\text { Demand to reinstate duty of } 5 \% \\
\text { (from duty-free) }\end{array}$ \\
48025690 & $\begin{array}{l}\text { SA-EU tariff phase-down (from 15\% to duty- } \\
\text { free by 2012) }\end{array}$ & $\begin{array}{l}\text { Demand for increase from duty- } \\
\text { free to 20\% }\end{array}$ \\
\hline 48101990 & From 5\% to duty-free & Demand for provisional duty \\
\hline
\end{tabular}

Source: ITAC, 2006, 2013

Analysis as to whether this change in tariffs brings diversification in terms of the number of countries from which South Africa imports shows that this number did not change much on the selected products. The range of countries per product remained in the band of 5 to 25 countries per product as shown in FIGURE 4.

This suggests that what was changing over time is not primarily the number of new countries (geographical extensive margin) that South Africa imports from, but rather the volume and value of already traded products (intensive margins). It shows that the increase in imports may have come from new countries that replaced other countries, or an increase in the volume of imports from existing trading partners

Disaggregating the analysis by countries with positive imports shows that imports are increasing from countries outside the EU. FIGURE 5, showing the HS48025520 product line (uncoated paper and paperboard), shows that imports are increasing from China, India and Singapore. This may suggest that recommending tariff reductions based on the SA-EU tariff phase-down is misleading given the surge in imports from countries for which South Africa has no obligation to reduce tariffs. 


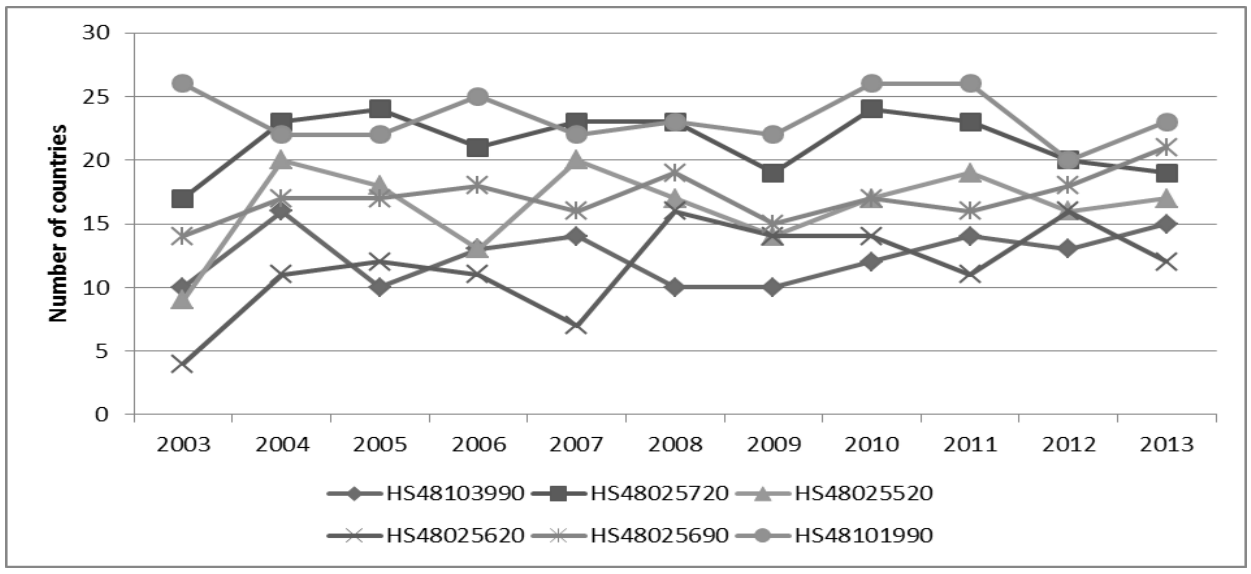

FIGURE 4: Number of countries where imports come from

\section{Source: Data from Quantec, 2014}

This trend is also evident for product line HS58101990, for which SAPA initiated an application for tariff reversal. Disaggregating imports by country shows that major imports come from nonEU member countries such as the Republic of Korea, China and Indonesia. This underscores the point that opening up to imports based on the $S A-\varepsilon U$ tariff phase-down has allowed for a rapid increase in imports from non- $E U$ countries. It suggests that in their analysis ITAC may have neglected the potential expansion in imports from these other emerging countries resulting from a tariff reduction.

PAMSA believes that at times ITAC takes too long to conclude a tariff investigation (Interview with PAMSA). This was raised mainly in relation to its application concerning tariffs on A4 paper, which has taken almost two years to be concluded. This tends to be costly to companies, particularly given changes in companies' cost structures and in variables such as the exchange rate and electricity costs. PAMSA also noted that there is a need for common relations among the government departments, as in PAMSA's view it seems that these departments work independently yet their objectives are interdependent. This is especially so given that tariff data is highly disaggregated and requires a deep understanding of the tariff book. Such enhanced cooperation could assist in reducing loopholes, which are often utilised by other players to 'cheat' the system by evading the tariffs using similar tariff lines.

This paper case study should be understood as a historical reflection of a case from almost nine years ago. A lot has changed since then, as seen in how ITAC changed its tariff policy, guidelines and adjudication criteria in line with the evolution of South Africa's trade policy.

\section{POULTRY CASE STUDY}

\subsection{Background}

The importation of poultry into the South African / Southern African Customs Union (SACU) market has been the subject of longstanding contestation. Policy reversals and disputes concerning tariffs have characterised the poultry sector since at least the year 2000 . 

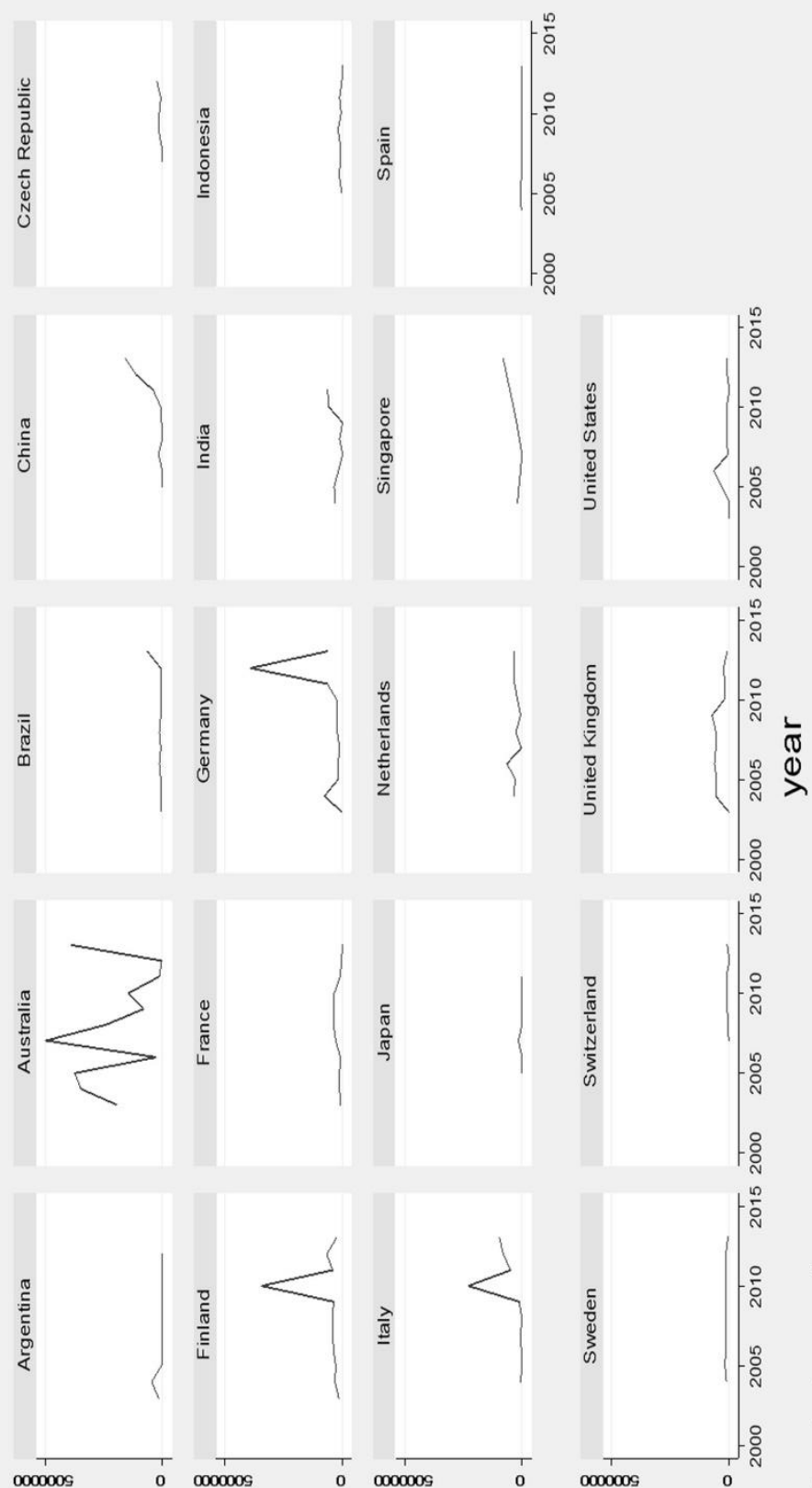

spodu!

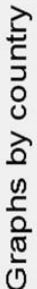


Before the current tariff regime on poultry, ITAC imposed provisional anti-dumping duties on imports from Brazil. These ranged between $46.59 \%$ on boneless cuts and $62.93 \%$ on whole birds in January 2012. These were challenged by the Brazilian government under the WTO's dispute settlement system and were subsequently reversed by South Africa's Minister of Trade and Industry on 8 March 2013 (ITAC Notice 173 of 2013). Instead the Minister called for a comprehensive strategy to deal with these imports from Brazil.

The poultry industry employs 48000 employees directly and another 60000 indirectly in supporting sectors. The poultry industry is vital to South Africa, as it is the largest agricultural subsector, contributing almost a quarter of agricultural gross domestic product. Poultry accounts for more than $65 \%$ of consumed animal protein in South Africa (SAPA, 2013b).

TABLE 3 shows domestic production and imports of chicken, in both levels and market share (percentage) terms. After declining from 2006, the share of imported chicken increased substantially from 2008 to 2012 .

\subsection{SAPA application and stakeholder concerns}

The South African Poultry Association (SAPA) applied for an increase in the rate of customs duty on poultry meat on 27 March 2013 (ITAC, 2013b). Since government designated the poultry sector as a sector in distress, the timeframe for ITAC's tariff investigation was four months instead of the usual six. ITAC followed the required tariff investigation process by first publishing a Notice in the Government Gazette (12 April 2013) inviting all interested parties to comment on the SAPA application.

TABLE 3: Comparison of domestic production and imports of chicken

\begin{tabular}{ccccc}
\hline Year & $\begin{array}{c}\text { Domestic production } \\
\text { (tonnes) }\end{array}$ & $\begin{array}{c}\text { Imports } \\
\text { (tonnes) }\end{array}$ & $\begin{array}{c}\text { Domestic } \\
\text { market share }\end{array}$ & $\begin{array}{c}\text { Import market } \\
\text { share }\end{array}$ \\
\hline 2006 & 1474952.58 & 181397 & $89.05 \%$ & $10.95 \%$ \\
2007 & 1534417.87 & 144888 & $91.37 \%$ & $8.63 \%$ \\
2008 & 1639277.33 & 98845 & $94.31 \%$ & $5.69 \%$ \\
2009 & 1652353.27 & 123230 & $93.06 \%$ & $6.94 \%$ \\
2010 & 1718616.42 & 138219 & $92.56 \%$ & $7.44 \%$ \\
2011 & 1736492.73 & 201696 & $89.59 \%$ & $10.41 \%$ \\
2012 & 1758772.04 & 238958 & $88.04 \%$ & $11.96 \%$ \\
\hline
\end{tabular}

Source: Data from SAPA, 2013a

Interested parties commented and made oral presentations (on 11 June 2013) concerning the proposed request. After considering the concerns and issues raised by all parties, on 5 August 2013 ITAC submitted to the Minister of Trade and Industry a request for an increase on import duties on five poultry products. The Minister granted the request on 29 August 2013, and it was subsequently implemented on 30 September 2013 by SARS (Notice 715, Government Gazette No. 36876). 
It is important to review what transpired in this sector that led to ITAC's decisions. The SAPA application was supported by poultry associations in the other SACU countries, namely Namib Poultry Industries (Pty) Ltd, Swazi Poultry Processors, Botswana Poultry Association and Basotho Poultry Farmers Association. This process was also supported by the Animal Feed Manufacturers Association, representing animal feed manufacturers in South Africa. SAPA requested an imposition of tariffs due to an increase in the volume of cheap frozen chicken imports, from almost 99000 tonnes in 2008 to almost 239000 tonnes in 2012. The reasons given by SAPA for tariff increases include jobs losses that had already occurred and the prospect of continued job losses due to company closures cases by increases in imports. They also cited the negative impact of low priced imports on further investment in the poultry industry, arguing that this could compromise SACU food security (Government Gazette No. 36358).

SAPA also used five major SACU producers in their justification. Five companies alone (Rainbow, Astral, Sovereign Food, AFGRI Poultry and Supreme Poultry) employ almost half (22 166) of the direct employees. These five companies claimed that 11995 direct jobs and 14892 indirect jobs were likely to be created if tariffs were to be imposed to their maximum rates of $82 \%$. The poultry producers argued that they were in distressed financial situations due to low-priced poultry imports. According to SAPA, the industry was in crisis and the (then-latest) company audited results show that Rainbow, Country Bird and Astral suffered 103\%, 150\% and $180 \%$ losses respectively (SAPA, 2013b). (All losses results are to June 2013 except for Astral, whose loss results are to March 2013.) SAPA attributed these losses to traditional exporters such as Brazil, Argentina and Thailand continuing to grow, whereas other countries were experiencing a global recession, while traditional importers such as Russia and China were becoming self-sufficient. This led to Africa becoming the greater target for the developed world's unwanted surpluses and those meat portions that developed countries do not want.

SAPA also argued that feed costs had increased by $20 \%$ for two consecutive years. Another reason cited is the increase in energy/electricity costs, which they said had more than doubled in four years. The request to increase tariffs was thus framed as being necessary in order to save the SACU poultry industry. SAPA presented projections as to the threatened losses in employment, restrictions on South Africa poultry exports to trading partners, cost disadvantages to the local industries, regulatory disadvantages of producers versus importers and the consequences that South Africa would face if imports were not halted and reversed. They argued that the imposition of duties would lead to benefits such as increased investment, employment and grain production, compared to costs such as increases in the prices for domestic consumers.

On the other hand, the Association for Meat Importers and Exporters (AMIE) opposed SAPA's call for a tariff hike. AMIE argued that imports from non- $\varepsilon U$ countries had declined by $35 \%$ from 2006 to 2013 , indicating no need for protection. They also submitted that the cost calculations by SAPA were wrong. According to AMIE, the depreciation of the rand had already provided $25 \%$ protection for local producers from January 2012 to June 2013 (AMIE, 2013).

AMIE regarded existing import duties on poultry and poultry parts, most of which were at $27 \%$, as being relatively high by international standards. Furthermore, AMIE characterised the domestic poultry industry as inefficient. By implication, tariff increases would be financing a bad business model of the poultry industry. The view presented by AMIE is that the poultry sector's problems derive from factors such as high input costs, including labour, electricity and animal feed, rather than from increased imports in recent years. From their perspective, tariff increases or trade remedies would thus not solve the poultry sector's problems. 
The view of the Competition Commission was that the poultry industry was not competitive (Ramburuth, 2013). From their investigations in 2009, the Competition Commission found elements of collusion among domestic chicken producers (Vecchiatto, 2013; Ramburuth, 2013). Their view was that the vertically integrated market structure which characterises the poultry industry incentivised anti-competitive behaviour, tie-in, supply agreements, information exchange and price-setting behaviour (Ramburuth, 2013).

\subsection{The outcome}

SAPA's request was granted at the end of September 2013, with tariff increases varying between $12 \%$ and $82 \%$ on all products as shown in TABLE 4 . Though ITAC increased the duties, it did not agree on customs duty combined with quantity restriction, as it did not find evidence of underinvoicing as claimed by SAPA. Further, ITAC recommended a slight increase of tariffs on offal and carcasses, given that they are an important source of protein for the poor (see TABLE 2). These increases, however, did not apply to European Union (EU) and Southern African Development Community (SADC) countries due to the existing free trade agreements (Government Gazette No. 36876).

TABLE 4: Increase in the rates of customs duty on frozen poultry

\begin{tabular}{|c|c|c|c|c|c|c|c|}
\hline $\begin{array}{c}\text { Tariff } \\
\text { subheading }\end{array}$ & $\begin{array}{c}\text { Product } \\
\text { description }\end{array}$ & $\begin{array}{c}\text { General duty } \\
\text { before the } \\
\text { increase on } \\
30 \text { September } \\
2013\end{array}$ & $\begin{array}{c}\text { Duty } \\
\text { proposed by } \\
\text { SAPA }\end{array}$ & $\begin{array}{l}\text { Type of duty } \\
\text { requested }\end{array}$ & $\begin{array}{c}\text { New } \\
\text { general } \\
\text { duty }\end{array}$ & $\begin{array}{l}\varepsilon U \text { and } \\
S A D C\end{array}$ & EFTA \\
\hline 0207.12 .20 & $\begin{array}{l}\text { Carcasses } \\
\text { with all cuts } \\
\text { removed }\end{array}$ & $27 \%$ & $\begin{array}{l}99 \mathrm{lc} / \mathrm{kg} \text { with } \\
\text { a maximum of } \\
82 \%\end{array}$ & $\begin{array}{l}\text { Specific duty } \\
\text { capped with } \\
\text { the bound } \\
\text { rate }\end{array}$ & $31 \%$ & Free & $31 \%$ \\
\hline 0207.12 .90 & $\begin{array}{l}\text { Other, whole } \\
\text { bird }\end{array}$ & $27 \%$ & $\begin{array}{l}111 \mathrm{c} / \mathrm{kg} \text { with } \\
\text { a maximum of } \\
82 \%\end{array}$ & $\begin{array}{l}\text { Specific duty } \\
\text { capped with } \\
\text { the bound } \\
\text { rate }\end{array}$ & $82 \%$ & Free & $82 \%$ \\
\hline 0207.14 .10 & Boneless cuts & $5 \%$ & $\begin{array}{l}12 \% \text { or } \\
220 \mathrm{c} / \mathrm{kg} \text { with } \\
\text { a maximum of } \\
82 \%\end{array}$ & $\begin{array}{l}\text { Combination } \\
\text { duty capped } \\
\text { with a bound } \\
\text { rate }\end{array}$ & $12 \%$ & Free & $12 \%$ \\
\hline 0207.14 .20 & Offal & $27 \%$ & $\begin{array}{l}67 \% \text { or } \\
335 \mathrm{c} / \mathrm{kg} \text { with } \\
\text { a maximum of } \\
82 \%\end{array}$ & $\begin{array}{l}\text { Combination } \\
\text { duty capped } \\
\text { with a bound } \\
\text { rate }\end{array}$ & $30 \%$ & Free & $30 \%$ \\
\hline 0207.14 .90 & $\begin{array}{l}\text { Other: bone- } \\
\text { in portions }\end{array}$ & $220 \mathrm{c} / \mathrm{kg}$ & $\begin{array}{l}56 \% \text { or } \\
653 \mathrm{c} / \mathrm{kg} \text { with } \\
\text { a maximum of } \\
82 \%\end{array}$ & $\begin{array}{l}\text { Combination } \\
\text { duty capped } \\
\text { with a bound } \\
\text { rate }\end{array}$ & $37 \%$ & Free & $37 \%$ \\
\hline
\end{tabular}

Source: Government Gazettes No. 36358, 12 April 2013 and 36876, 30 September 2013.

In accepting the ITAC recommendation, the Minister of Trade and Industry stipulated five conditions that should hold for the tariff to remain in the future (DTI, 2013). Firstly, there is a need for an early review of the new tariffs to assess their impact. Secondly, the Minister expects 
that the question of brining will be satisfactorily addressed through new regulations. Thirdly, the Minister expects that the established poultry industry would make meaningful undertakings to support the development of small-scale poultry farmers. Fourthly, the Minister expects that providing this support will enable the poultry industry to work to encourage fair competition in the domestic market. Finally, these measures are designed to support and promote the poultry producers across the entire SACU market to ensure a sustainable and competitive industry that is able to provide greater food security to the region's people.

\subsection{Analysis}

ITAC's decision can be evaluated on the basis of the time taken to reach the decision, information used to evaluate different positions advanced by stakeholders, the position of $\varepsilon U$ imports, the general view of industry stakeholders, and the balancing of competing considerations.

One issue is the impact of import duties on possible competition within the domestic poultry industry. The duties could enhance anti-competitive behaviour, which has already been identified by the Competition Commission. From the perspective of the Competition Commission, imports are necessary to force competition in the domestic poultry market, since an increase in tariffs would reduce choice and result in higher prices for consumers (Ramburuth, 2013).

Grimbeek and Lekezwa (2013) argue that an increase in domestic competition from domestic producers (not foreign competition) may reduce profit margins. For instance, they show that profit margins had been increasing up until 2007, when Country Bird exited the Elite partnership and introduced some form of competitive pressure. This could indicate that as more imports enter, profit margins might decline further, which could support the views raised by SAPA. However, the fact that most recent poultry imports are from the $E U$ - which would not face import tariff increase due to the Free Trade Agreement - suggests that tariff increases would not be fully effective, as the import tariff would affect only a fairly small percentage of imports.

In addition, vertical integration in the local industry reduces domestic competition. Five producers - Rainbow Farms, Astral Operation, Sovereign Food investment, AFGRI Poultry and Supreme Poultry - account for approximately half of total SACU production.

Some of the points raised by SAPA for justifying tariff increases are not directly related to imports but rather to inefficiencies or other problems in the poultry industry. For example, the high cost of electricity, high input costs such as from grain feed and fuel, high logistics cost between urban centres and an ineffective rail system has nothing to do with increased imports. Reduction in imports would not lessen these high costs. Instead, interventions in other spheres would be needed to address these problems.

In terms of duration, the investigation was not concluded by ITAC in the stipulated four months. The tariff investigation process started on 27 March 2013 and ended on 30 September 2013, which is about six months, which is the timeframe for standard tariff investigations, whereas the poultry sector had been designated a sector in distress. This delay in reaching and announcing the decision has undesirable implications. According to $A M I E$, this delay in announcing the final tariff decision led to speculation, causing real market distortions (AMIE, 2013). Further, the delay in announcing the final tariff decision might have been overtaken by macroeconomic events such as the depreciation of the rand. This depreciation alone acts as a protective measure, since imports become more expensive for South Africans, and as such the depreciation 
might have already changed the import position/status of the poultry products into South Africa and hence affected the appropriate recommendations.

As part of its investigation ITAC carried out a consumer impact assessment. ITAC found that tariff increases would have price-raising effects (albeit relatively low and varying with the level of tariff increases). Fourie (2013) found that a tariff increase would lead to increases in the costs to consumers, especially to the poor. The point was supported by AMIE, who argued that an increase in import tariffs would have net effects of raising food prices by about $30 \%$. To AMIE, the increase in poultry prices was further necessitated by the fact that the domestic poultry industry was controlled by large vertically integrated local participants. SAPA did not dispute the possibility of price increases as a result of a tariff increase, but they argued that it would be less than a $10 \%$ price increase (SAPA, 2013b). Even the Competition Commission points out that increased import tariffs may mean less product choice and higher prices, which might deny consumers the benefits of increased import competition (Ramburuth, 2013).

The fact that $\varepsilon U$ and SADC imports are duty-free (which is beyond the control of ITAC) points to a possible loophole. There is a strong possibility of imports to South Africa being diverted through these regional blocs. Evidence also shows that imports of poultry have of late been coming through $\varepsilon U$ countries rather than Brazil. About $55 \%$ of all poultry imports now come from the $E U$, and only $29 \%$ come from Brazil. Imports of frozen chicken legs from the $\varepsilon U$ increased by $72 \%$ in 2012. This was possibly due, at least in part, to the tariff already imposed on Brazil (Ramburuth, 2013). This implies that the imposition of the tariffs will not be fully effective in curbing increased imports of poultry products into South Africa. Furthermore, according to AMIE these protectionist activities might also result in retaliatory measures by some trading partners, as had already begun occurring with some agricultural products.

As shown in FIGURE 6, Europe has overtaken the Americas in supplying other bone-in portions (tariff line HS02071490) to South Africa. With offal (tariff line HS02071420) Europe is almost overtaking the Americas.

Despite this trend, Brazil still dominates in other poultry products. At country level Brazil was the major exporter to South Africa until May 2011, when it was overtaken by the Netherlands. There has also been an upward surge in imports from EU countries such as Germany and United Kingdom of tariff line HS02071490 as shown in FIGURE 7.

Increasing tariffs for other countries and trading duty-free with $\mathrm{EU}$ countries may not result in the intended benefits from the protection. Based on this analysis it is evident that increasing poultry import tariffs may lead to a shift or diversion of imports (through the $\varepsilon U$ instead of through South America) rather than an overall reduction in poultry imports, hence the desired benefits of tariff increase will be diminished. If the free trade area between South Africa and EU continues to hold, the longer-term solution for the growth of the poultry industry lies in increasing competitiveness and reducing high feed costs, electricity, and transport costs. Tariffs (and other trade-related measures) nevertheless retain an important role, particularly for the retention of employment in the domestic poultry industry. 

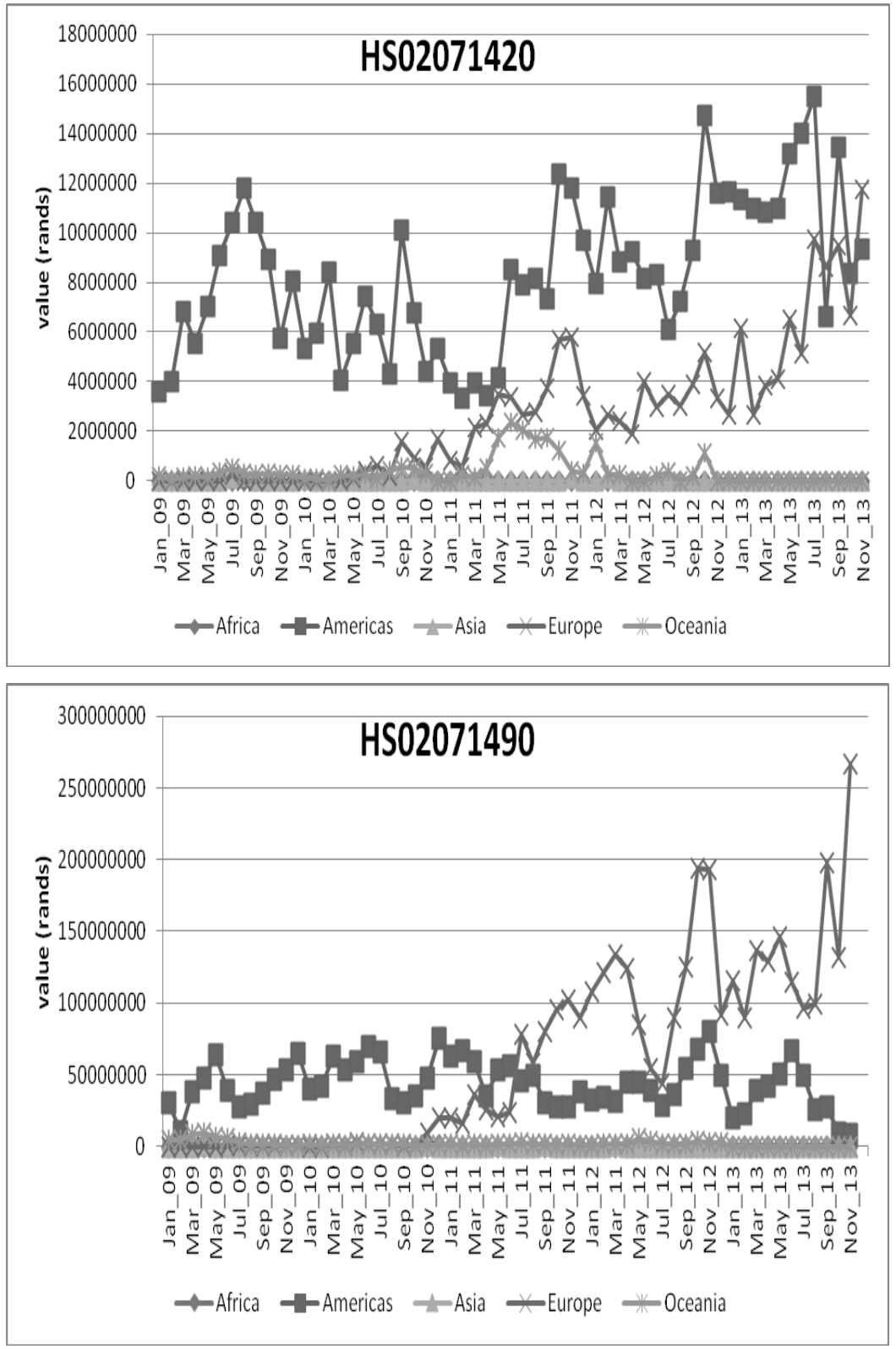

FIGURE 6: Trends in import structure of offal and other bone-in portions across continents

Source: Data from Quantec, 2014

Note: Tariff line HS02071420 is offal, tariff line HS02071490 is other bone-in portions. 


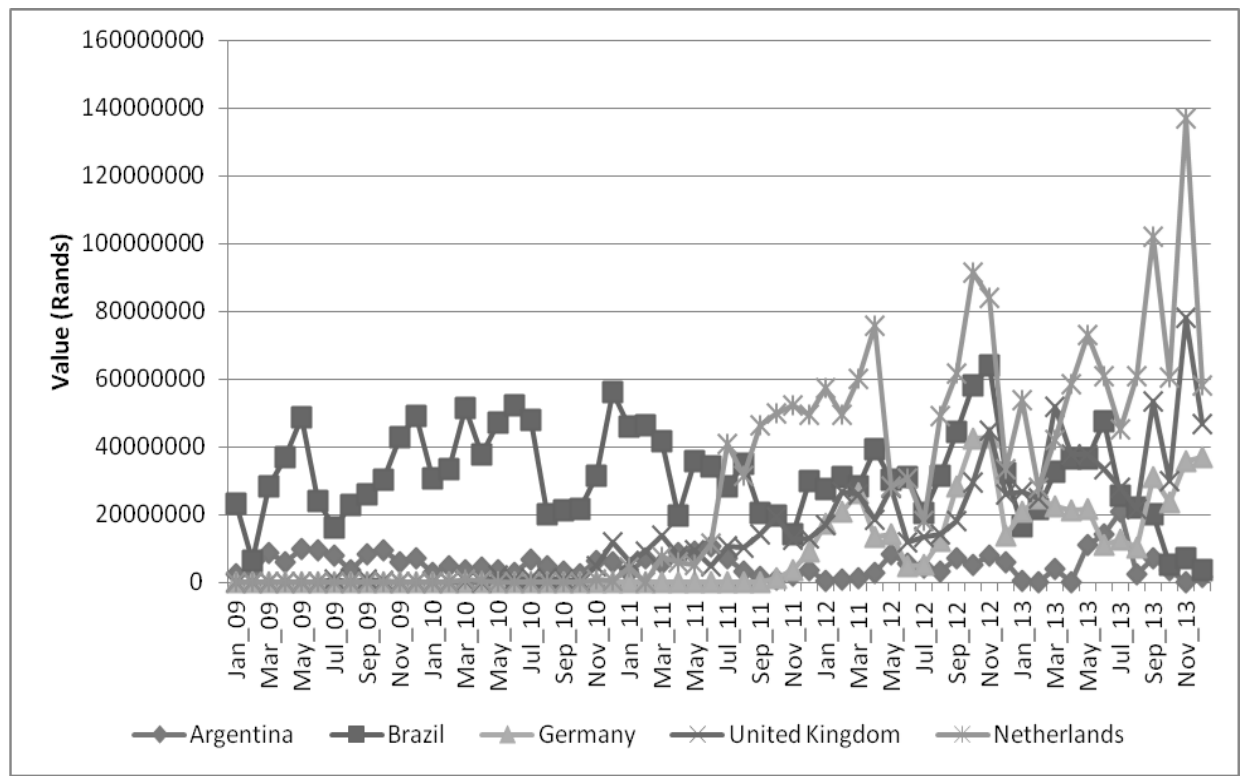

FIGURE 7: Trend in import structure of other bone-in portions across countries

Source: Data from Quantec, 2014

The differentiated outcomes for different types of poultry products are an important demonstration of the attempt at achieving a balance between different and often competing objectives by ITAC. A central challenge with which ITAC needs to grapple in every case is how to balance the different interests along the value chain, as well as how to balance the interests of producers and consumers. The extremely high rate of unemployment in South Africa means that the retention and creation of employment features as a central consideration in any decision, with this being balanced against other considerations such as access to affordable products for consumers. ITAC attempted to achieve an appropriate balance by recommending differentiated tariffs for different types of poultry products, with those consumed predominantly by lowincome consumers being subjected to lower tariffs than those consumed predominantly by highincome consumers (see TABLE 4). Such differentiated tariffs are an important way of balancing the interests of producers (including employment retention and creation) with those of consumers (especially for foodstuffs consumed predominantly by low-income consumers).

\section{CONCLUSION}

The results of this study indicate that ITAC managed to follow and implement the changes in government trade policy in the cases analysed. Before 2009 the South African government was pursuing trade liberalisation, hence the decline in tariffs on paper products. After 2009 the government put more emphasis on promotion of industrial growth and the retention and creation of employment through trade policy, hence the increase in tariffs on poultry products.

Our findings also suggest that ITAC does undertake thorough and nuanced analysis before recommending changes in tariff regimes, as evidenced by differential increase of tariffs on poultry products. However, ITAC should conduct a rigorous analysis of global trade dynamics and 
the implications of existing trade agreements. This is evident for instance with the tariffs imposed on poultry imports while there is duty-free with the $E U$ and SADC, providing a possible loophole for the circumvention of the tariffs. This weakness is also evident in the paper case study, where countries not covered by the $S A-\varepsilon U$ trade agreement emerge as the largest exporters to South Africa after the decline in paper products tariffs.

The findings also demonstrate that ITAC should work closely with other government departments and other regulators - notably the Competition Commission - to ensure policy consistency. This is evidenced by the divergent views of ITAC and the Competition Commission concerning the poultry sector.

It is important that ITAC expedites tariff investigations. As discussed here with reference to the poultry and paper cases, lengthy tariff investigations can be overtaken by relevant changes, such as in the macroeconomic environment. Delays can also have deleterious effects on investment and employment. This is particularly important for a sector in distress, such as poultry. A well-trained and appropriately skilled investigation team, with an adequate staff complement and capacity, is therefore crucial. Additional policy implications and recommendations, focused on the institutional dimension in particular, are discussed in the companion article to this one, titled 'An Institutional Analysis of the International Trade Administration Commission of South Africa'.

Acknowledgement

This article draws on research undertaken as part of the Regulatory Entities Capacity Building Project, with funding from the South African government's Economic Development Department. The authors thank all those who made themselves available for interviews and provided valuable information and insights.

\section{LIST OF REFERENCES}

Association for Meat Importers and Exporters (AMIE). (2013). Presentation to Parliamentary Portfolio on Agriculture, Forestry and Fisheries. [Online] Available: http://www.pmg.org.za/report/20130910status-poultry-tariffs-in-sa-impact-proposed-tariff-increase-for-poultry-imports-inputcompetition-commission $\backslash$ (Accessed 15 April 2014)

Datt, M., Hoekman, B. \& Malouche, M. (2011). Taking stock of trade protectionism since 2008. World Bank, Working Paper Series No.72.

Department of Trade and Industry (DTI). (2010). A South Africa Trade Policy and Strategy Framework. Pretoria: Department of Trade and Industry.

Department of Trade and Industry (DTI). (2013). Media Statement by the Department of Trade and Industry on Tariff Increases with Respect to Certain Poultry Products. Pretoria: Department of Trade and Industry.

Draper, P. \& Alves, P. (2010). Trade Reform in Southern Africa: Vision 2014? Auckland Park: Jacana Media.

Fiandeiro, M.F. \& Rankin, N. (2008). Trade liberalisation and wages in South African manufacturing. Mimeo: University of the Witwatersrand. 
Fourie, H. (2013). Not a Free Lunch: The Implications of Increased Import Tariffs on South Africa's Chicken Market. In Econex: Trade, Competition and Applied Economics, (Research Note 31).

Government of the Republic of South Africa. (2002). International Trade Administration Act No. 71 of 2002. Government Gazette No. 24287. Cape Town: Government of the Republic of South Africa.

Government of the Republic of South Africa. (2013). Government Gazette No. 36951. Cape Town: Government of the Republic of South Africa.

Grimbeek, S. \& Lekezwa B. (2013). The emergence of more vigorous competition and the importance of entry - comparative insights from flour and poultry. Centre for Competition Economics. (Working Paper Series No. 2013).

Harding, T. \& Rattsø, J. (2010). Industrial labour productivities and tariffs in South Africa. Economics of Transition. 18, pp. 459-485.

International Trade Administration Commission of South Africa (ITAC). (2013a). Annual Report 20122013. Pretoria: International Trade Administration Commission of South Africa.

International Trade Administration Commission of South Africa (ITAC). (2013b). Final Decision in the Investigation into the Alleged Dumping of Frozen Meat of Fowls of the Species Gallus Domesticus, Whole Bird and Boneless Cuts Originating in or Imported from Brazil. Pretoria: International Trade Administration Commission of South Africa.

Paper Manufacturers Association of South Africa (PAMSA). (2013). Annual Report.

Presidency of the Republic of South Africa. (2014). Twenty Year Review: South Africa 19942014.Pretoria: Presidency of the Republic of South Africa.

Quantec. (2014). [Online] Available: http://www.quantec.co.za/ (Accessed 5 January 2014)

Ramburuth, R. (2013). The impact of poultry tariff on competition. Presentation to Parliamentary Portfolio on Agriculture, Forestry and Fisheries. [Online] Available:

http://db3sqepoi5n3s.cloudfront.net/files/130910impact.pdf (Accessed 17 February 2014)

Southern African Poultry Association (SAPA). (2013a) [Online] Available:.

http://www.sapoultry.co.za/ (Accessed 17 February 2014)

Southern African Poultry Association (SAPA). (2013b). Presentation to Parliamentary Portfolio on Agriculture, Forestry and Fisheries, 10 September 2013. [Online] Available:

http://www.pmg.org.za/report/20130910-status-poultry-tariffs-in-sa-impact-proposed-tariffincrease-for-poultry-imports-input-competition-commission $\backslash$ (Accessed 17 February 2014)

Tregenna, F. (2011). A new growth path for South Africa? Review of African Political Economy, 38(130), pp. 627-635.

Tregenna, F. (2012). Sources of subsectoral growth in South Africa. Oxford Development Studies, 40(2), pp. 162-189.

Thurlow, J. (2006). Has trade liberalization in South Africa affected men and women differently? International Food Policy Research Institute. Discussion Paper No. 36.

Vecchiatto, P. (2013). Poultry debate exposes tariff tensions. Business Daylive. [Online] Available: http://www.bdlive.co.za/business/trade/2013/09/11/poultry-debate-exposes-tariff-tensions. (Accessed 18 December 2013). 


\section{APPENDIX: LIST OF INTERVIEWEES}

The following persons were interviewed for the purposes of this research.

Mr S Tsengiwe, Chief Commissioner, ITAC, 3 December 2013

Ms Z Xabendlini, Senior Manager: Trade Remedies II, ITAC, 3 December 2013

Ms R Theart, Senior Manager: Tariff Investigations I, ITAC, 3 December 2013

Mr T Chauke, Director, DTI, 3 December 2013

Prof S Roberts, Director, Centre for Competition, Regulation and Economic Development, 12

December 2013

Ms L Mndebela, Senior Manager: Human Resources, ITAC, 17 December 2013

Dr M Obinyeluaku, Chief Economist, ITAC, 17 December 2013

Ms J Molony, Chief Executive Officer, PAMSA, 24 January 2014

Mr P Bortolon, Business Manager Paper, Sappi, 24 January 2014

Mr L Kelvin, Chief Executive Officer, SAPA Chief Executive Officer , 31 January 2014

Mr $\varepsilon$ Vlok, Trade Specialist, Economic Development Department and Part-time Commissioner at ITAC, 14 March 2014 
Kwaramba \& Tregenna 